\title{
ANALISIS RONA AWAL LINGKUNGAN DARI PENGOLAHAN CITRA LANDSAT 7 ETM+ (Studi Kasus :Daerah Eksplorasi Geothermal Kecamatan Sempol, Bondowoso)
}

\author{
Hana Sugiastu Firdaus ${ }^{1}$, Muhammad Taufik ${ }^{2}$, Widya Utama $^{3}$ \\ ${ }^{1}$ Program Studi Teknik Geomatika FTSP-ITS, Kampus ITS Sukolilo, Surabaya, 60111 \\ ${ }^{2}$ Program Studi Teknik Geofisika FTSP-ITS, Kampus ITS Sukolilo, Surabaya, 60111 \\ Email : hanasugiastufirdaus@gmail.com, taufik_srmd@yahoo.com,widutama@yahoo.fr
}

\begin{abstract}
Abstrak
Rona awal lingkungan merupakan kondisi lingkungan yang berupa kondisi alam atau komponen-komponen lingkungan awal sebelum perencanaan dan pembangunan fisik dimulai . Sebelum melakukan kegiatan eksplorasi geothermal, penguraian rona awal lingkungan sangatlah diperlukan sebagai dasar dari upaya pengelolaan dan pemantauan lingkungan (UKL\&UPL) dalam meniminamalisir dampak yang ditimbulkan. Penguraian rona awal lingkungan pada penelitian ini didapat dari pengolahan citra Landsat 7 ETM+ untuk mendapatkan gambaran kondisi tutupan lahan dan kerapatan vegetasi di area studi, serta data sekunder sebagai pelengkap komponen lingkungan lainnya. Penentuan nilai kerapatan vegetasi didasarkan dari tutupan lahan yang dominan yaitu perkebunan, hutan dan semak belukar. NDVI (Normalized Difference Vegetation Index) dan SAVI (Soil Adjusted Vegetation Index) merupakan algoritma yang digunakan dalam penentuan kerapatan vegetasi. Dua algoritma yang digunakan dikorelasikan dengan suhu permukaan tanah (SPT) untuk mendapatkan algoritma yang terbaik dalam penentuan kerapatan vegetasi . Korelasi terbaik untuk area perkebunan dan hutan didapatkan dari algoritma NDVI sedangkan SAVI untuk semak belukar. Area studi yang digunakan dalam penelitian ini, yaitu Kecamatan Sempol, Bondowoso, Jawa Timur.
\end{abstract}

Kata Kunci : Rona Awal Lingkungan Landsat 7 ETM+, NDVI, SAVI, SPT,

\section{PENDAHULUAN}

Panas bumi atau geothermal adalah sumber energi panas yang terkandung di dalam air panas, uap air, dan batuan bersama mineral ikutan dan gas lainnya yang secara genetik semuanya tidak dapat dipisahkan dalam suatu sistem panas bumi dan untuk pemanfaatannya diperlukan proses penambangan (UU No.27, 2003). Proses penambangan termasuk di dalamnya kegiatan eksplorasi diperlukan adanya upaya pengelolaan lingkungan (UKL) dari sumber dampak yang ditimbulkan. Pengelolaan lingkungan hidup adalah upaya terpadu untuk melestarikan fungsi lingkungan hidup yang meliputi kebijaksanaan penataan, pemanfaatan, pengembangan, pemeliharaan, pemulihan, pengawasan, dan pengendalian lingkungan hidup (UU No.23, 2003).

Upaya dalam melestarikan fungsi lingkungan untuk meminimalisir dari dampak yang ditimbulkan didasarkan dari uraian rona awal lingkungan dan prediksi perubahan rona awal lingkungan jika dilakukan kegiatan eksploasi. Penguraian rona awal lingkungan didasarkan dari pengolahan data primer dan data sekunder 58
(Dokumen UKL-UPL dan RTRW Bondowoso). Pengolahan citra Landsat (Land Satellites) 7 ETM+ digunakan untuk mendapatkan tutupan lahan dan kerapatan vegetasi di area studi. Algoritma yang digunakan dalam penentuan nilai kerapatan vegetasi yaitu NDVI (Normalized Difference Vegetation Index) dan SAVI (Soil Adjusted Vegetation Index) dimana hasil yang didapat dilakukan korelasi dengan nilai suhu permukaan tanah (SPT) untuk mendapatkan algoritma yang terbaik. Kerapatan vegetasi memiliki hubungan yang erat dengan suhu permukaan tanah (SPT) dikarenakan rentang nilainya dipengaruhi oleh kondisi tumbuhan disekitarnya, selain itu karena area studi merupakan daerah potensi panas bumi dengan parameter SPT yang relatif cukup tinggi.

Nilai kerapatan vegetasi didasarkan dari tutupan lahan yang dominan yaitu perkebunan, hutan dan semak belukar. Metode yang digunakan untuk mendapatkan tutupan lahan di area studi yaitu menggunakan klasifikasi terselia (supervised classification) dengan prosedur pengenalan pola spektral dengan memilih kelompok atau kelaskelas informasi yang diinginkan dan selanjutnya memilih contoh-contoh kelas (training area) yang 
mewakili setiap kelompok (Lillesend, 2004). Klasifikasi terselia didasarkan dari perhitungan statistika minimum distance.

Penggambaran topografi di area studi didasarkan dari Peta RBI . Nilai ketinggian dan kelerengan didapatakan dari proses pengolahan data kontur. Sedangkan, parameter fisik tanah, air dan udara didapatkan dari data sekunder.

\section{METODOLOGI PENELITIAN}

Area studi yang digunakan pada penelitian terletak di Kecamatan Sempol, Kabupaten Bondowoso, Jawa Timur.

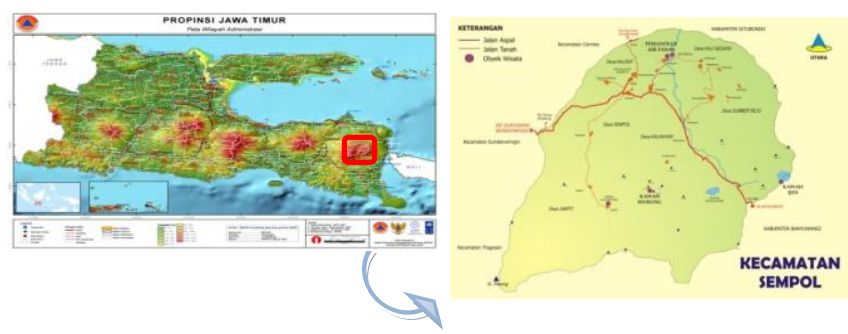

Gambar 1. Lokasi Penelitian

(Sumber : Kecamatan Sempol Dalam Angka, 2012)

Diagram alir pengolahan data dalam penelitian ini, dapat dilihat pada gambar 2 .

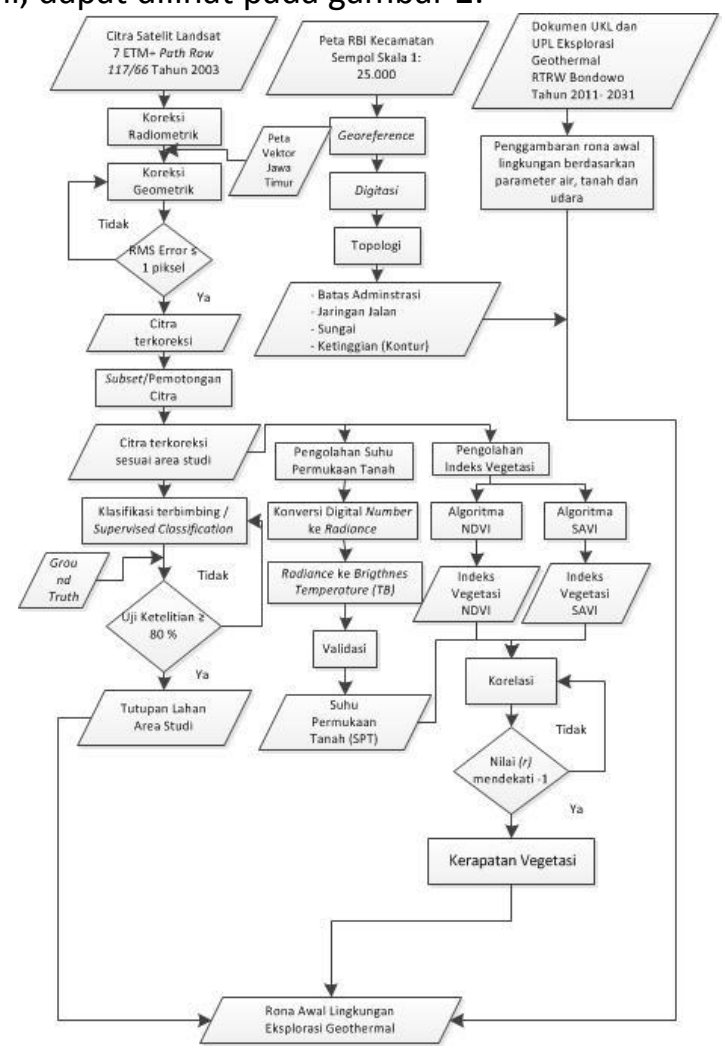

Gambar 2. Diagram Alir Pengolahan Data
Penggambaran rona awal lingkungan dari pengolahan citra satelit Landsat $7 \mathrm{ETM}+$ path/row 117/66 tahun 2003 dengan menggunakan parameter tutupan lahan, kerapatan vegetasi area studi. Tutupan lahan diperoleh dengan menggunakan klasifikasi terselia (supervised classification) berdasarkan perhitungan statistika minimum distance. Kerapatan vegetasi didapatkan dari perhitungan algoritma NDVI dan SAVI yang selanjutnya dilakukan korelasi dengan SPT untuk mendapatkan algoritma yang terbaik dimana nilai SPT didasarkan dari konversi nilai digital number ke dalam nilai spectral radiance $(L \lambda)$ yang selanjutnya dikonversi dalam brightness temperature (TB). Persamaan NDVI dan SAVI yang digunakan yaitu sebagai berikut :

$$
\begin{aligned}
& N D V I=\frac{\rho \text { nir }-\rho r e d}{\rho n i r+\rho r e d} \\
& S A V I=[\rho n i r-\rho r e d) /(\rho n i r+\rho r e d+L]
\end{aligned}
$$

onir merupakan nilai reflektan gelombang near infrared sedangkan pred nilai reflektan gelombang red Besarnya L (faktor koreksi terhadap background kanopi) yang digunakan dalam penelitian ini adalah 0,6 .

Dalam penelitian ini, analisa yang dilakukan yaitu analisa ketelitian dari penggambaran tutupan lahan, korelasi antara algoritma (NDVI dan SAVI) dengan SPT, analisa penentuan nilai kerapatan vegetasi di area studi.

\section{HASIL DAN PEMBAHASAN}

A. Hasil Koreksi Geometrik Citra Landsat 7 ETM+

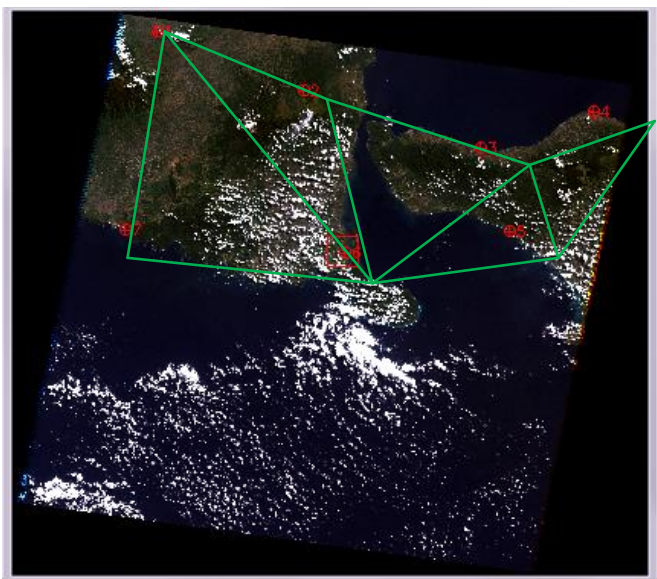

Gambar 3. Sebaran Ground Control Point 
Untuk koreksi geometrik diberikan toleransi nilai RMSE $\leq 1$ piksel dan untuk jaring titik kontrol ditentukan dengan meletakkan titik-titik kontrol yang merata meliputi daerah studi dengan nilai toleransi SOF (Strength of Figure) kurang dari 1 dimana semakin kecil faktor bilangan SOF maka semakin baik pula konfigurasi jaringan dari jaring tersebut dan sebaliknya (Abidin, 2002). Hasil perhitungan RMS Error didapat 0,018 dengan besar SOF yaitu :

$$
\text { SOF }=\frac{\left[\operatorname{Trace}\left(\mathrm{A}^{\mathrm{T}} \mathrm{A}\right)^{-1}\right]}{\text { Jumlah Parameter }}=0,642
$$

\section{B. Hasil Tutupan Lahan Citra Landsat 7 ETM+ dengan Klasifikasi Terselia berdasarkan minimum distance}

Klasifikasi tutupan lahan area studi didominasi oleh hutan, semak belukar dan perkebunan. Luas area tutupan lahan selengkapnya dapat dilihat pada tabel 1. Hasil tutupan lahan di area studi dari pengolahan citra dapat dilihat pada gambar 4 . Tutupan lahan yang telah diolah selanjutnya dilakukan pengecakan lapangan (ground truth), dan hasil yang didapat menunjukkan hasil tutupan lahan yang telah diolah dapat merepresentasikan $71,43 \%$ tutupan lahan dalam temporal waktu saat ini (tahun 2012).

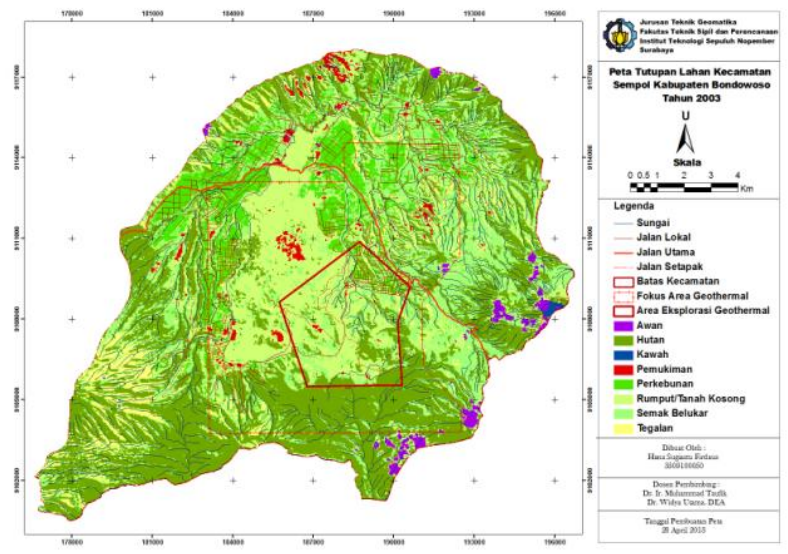

Gambar 4. Tutupan Lahan Kecamatan Sempol, Bondowoso
Tabel 1. Luas Tutupan Lahan Kecamatan Sempol, Kabupaten Bondowoso Tahun 2003

\begin{tabular}{lr}
\hline \hline \multicolumn{1}{c}{ Kelas } & \multicolumn{1}{c}{ Luas (Ha) } \\
\hline Hutan & 8012,97 \\
Kawah & 21,15 \\
Perkebunan & 2189,16 \\
Semak Belukar & 6059,88 \\
Rumput/Tanah Kosong & 3384,72 \\
Tegalan & 1386,63 \\
Pemukiman & 269,01 \\
Jumlah & $\mathbf{2 1 3 2 3 , 5 2}$ \\
\hline \hline
\end{tabular}

\section{Hasil Pengolahan SPT, NDVI, dan SAVI beserta korelasinya tiap kelas}

Area yang dominan di lokasi penelitian selanjutnya dilakukan perhitungan nilai indeks vegetasi untuk menentukan kerapatan vegetasi dengan dua algoritma yaitu NDVI dan SAVI dimana hasil yang diperoleh dikorelasikan dengan SPT. Korelasi terbaik digunakan untuk menentukan rentang kerapatan vegetasi tiap kelas. Rentang nilai indeks vegetasi NDVI, SAVI dan SPT dapat dilihat pada tabel 2 sedangkan korelasi dapat dilihat pada tabel 3 .

Tabel 2. Nilai Indeks Vegetasi NDVI, SAVI dan SPT Kecamatan Sempol, Kabupaten Bondowoso Tahun 2003

\begin{tabular}{|c|c|c|}
\hline \multirow{2}{*}{ Kelas } & \multicolumn{2}{|c|}{ Nilai NDVI } \\
\hline & $\min$ & $\max$ \\
\hline Hutan & $-0,542$ & 0,583 \\
\hline Perkebunan & 0,346 & 0,608 \\
\hline \multirow[t]{2}{*}{ Semak Belukar } & $-0,053$ & 0,559 \\
\hline & \multicolumn{2}{|c|}{ Nilai SAVI } \\
\hline Kelas & $\min$ & $\max$ \\
\hline
\end{tabular}




\begin{tabular}{lcc}
\hline Hutan & $-0,488$ & 0,554 \\
Perkebunan & 0,332 & 0,584 \\
Semak Belukar & $-0,054$ & 0,532 \\
\hline \multicolumn{1}{c}{ Kelas } & \multicolumn{2}{c}{ Nilai SPT } \\
\cline { 2 - 3 } & Min $\left.{ }^{\circ} \mathrm{C}\right)$ & Max $\left(^{\circ} \mathrm{C}\right)$ \\
\hline Hutan & 12.43 & 39,96 \\
Perkebunan & 22,33 & 37,46 \\
Semak Belukar & 15,74 & 35,53 \\
\hline
\end{tabular}

Tabel 3. Hasil korelasi Nilai SPT dengan NDVI dan SAVI

\begin{tabular}{lcccc}
\hline \multirow{2}{*}{ Kelas } & \multicolumn{4}{c}{ Korelasi } \\
\cline { 2 - 5 } & $\begin{array}{c}\text { SPT } \\
\text { dengan } \\
\text { NDVI }\end{array}$ & $\%$ & $\begin{array}{c}\text { SPT } \\
\text { dengan } \\
\text { SAVI }\end{array}$ & $\%$ \\
& & & & \\
\hline Hutan & $-0,657$ & 65,7 & $-0,656$ & 65,6 \\
Perkebunan & $-0,825$ & 82,5 & $-0,824$ & 82,4 \\
Semak Belukar & $-0,646$ & 64,6 & $-0,652$ & 65,2 \\
\hline \hline
\end{tabular}

Tanda minus menunjukkan hubungan berkebalikan antara SPT dengan indeks vegetasi atau dapat dikatan semakin tinggi suhu permukaan tanah maka semakin rendah atau sedikit tumbuhan yang berada di sekitarnya. Pengambilan sample yang dikorelasikan dipilih secara acak dan tersebar merata. Korelasi terbaik dari tiap kelas dapat digunakan untuk menentukan rentang kerapatan vegetasi Hasil korelasi terbaik pada tiap kelas dapat dilihat pada gambar 5, 6 dan 7 .

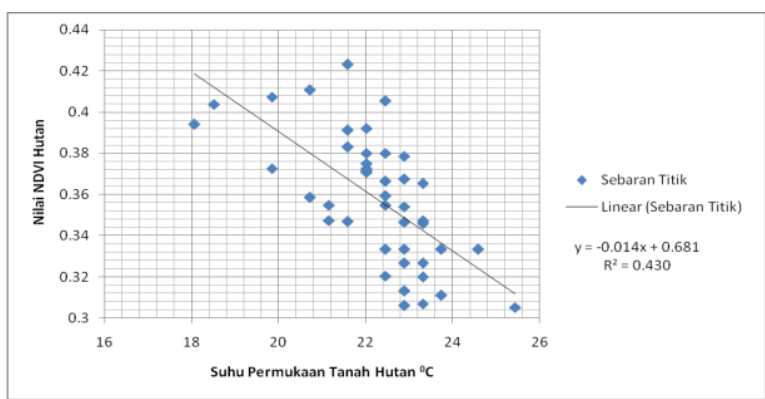

Gambar 5. Hasil korelasi SPT dengan NDVI untuk Kawasan Hutan

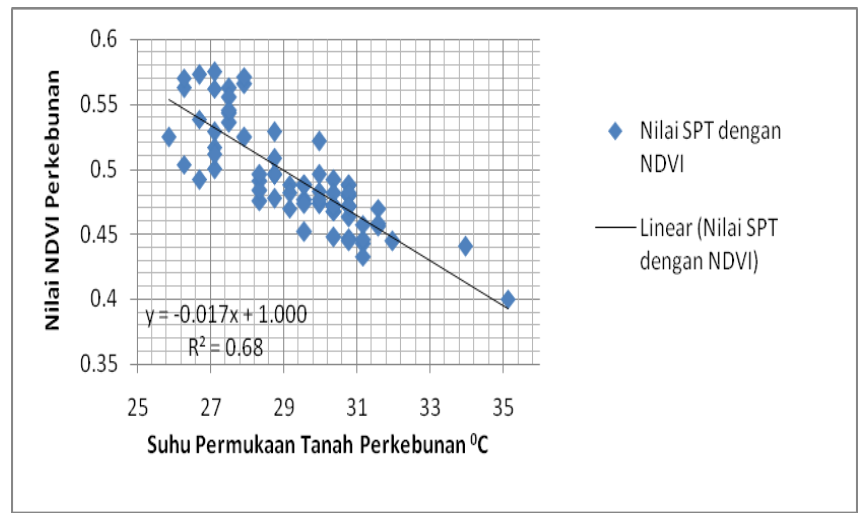

Gambar 6. Hasil Korelasi SPT dengan NDVI untuk daerah Perkebunan

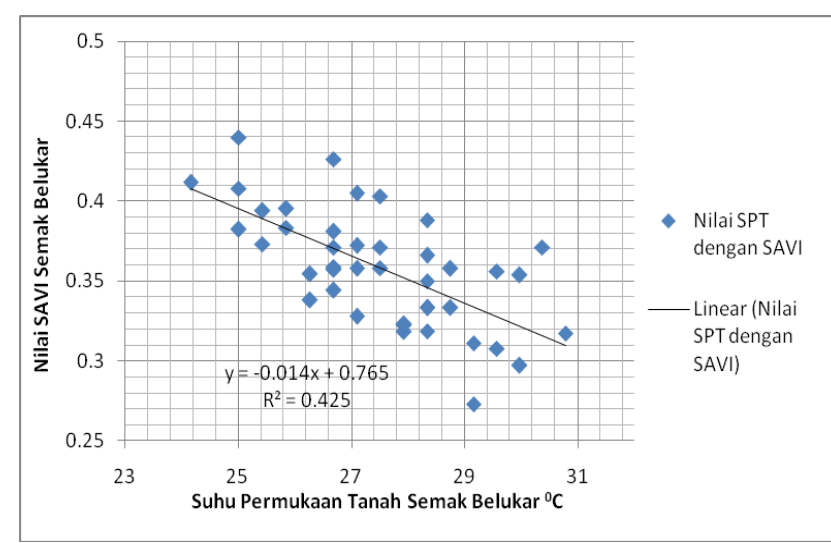

Gambar 7. Hasil korelasi SPT dengan SAVI untuk Kawasan Semak Belukar

Penentuan tingkat kerapatan vegetasi untuk tutupan lahan hutan dan perkebunan didasarkan dari klasifikasi tingkat kerapatan NDVI berdasarkan sumber Departemen Kehutan, 2003 pada tabel 4. Sedangkan untuk semak belukar yang didasarkan dari algoritma SAVI, pengklasifikasian tingkat kerapatannya berdasarkan subyektif yang tetap mengacu dari tingkat kerapatan NDVI, dikarenakan perbedaan nilai yang tidak terlalu signifikan antara SAVI dan NDVI. Pengkelasan kerapatan vegetasi dari kelas tutupan lahan tersebut secara berurutan dapat dilihat pada tabel 5, 6 dan 7 .

Tabel 4. Kisaran Tingkat Kerapatan NDVI

\begin{tabular}{ccc}
\hline \hline Kelas & Kisaran NDVI & Tingkat Kerapatan \\
\hline 1 & $-1,0$ s.d 0,32 & Jarang \\
2 & 0,32 s.d 0,42 & Sedang \\
3 & 0,42 s.d 1 & Tinggi \\
\hline \hline
\end{tabular}

(Sumber : Departemen Kehutanan, 2003) 
Tabel 5. Tingkat Kerapatan Vegetasi Daerah Hutan

\begin{tabular}{cccc}
\hline \hline Kelas & Minimum & Maximum & Kerapatan \\
\hline 1 & $-0,053637$ & 0,011462 & Jarang \\
2 & 0,011463 & 0,076562 & Jarang \\
3 & 0,076563 & 0,141661 & Jarang \\
4 & 0,141662 & 0,206761 & Jarang \\
5 & 0,206762 & 0,271860 & Jarang \\
6 & 0,271861 & 0,336960 & Jarang \\
7 & 0,336961 & 0,402059 & Sedang \\
8 & 0,402060 & 0,467159 & Sedang \\
9 & 0,467160 & 0,532258 & Tinggi \\
\hline \hline
\end{tabular}

(Sumber : Disesuaiakan dengan kisaran tingkat kerapatan Departemen, Kehutanan )

Tabel 6. Tingkat Kerapatan Vegetasi Daerah Perkebunan

\begin{tabular}{cccc}
\hline \hline Kelas & Minimum & Maximum & Kerapatan \\
\hline 1 & $-0,541586$ & $-0,416675$ & Jarang \\
2 & $-0,416676$ & $-0,291765$ & Jarang \\
3 & -0.291766 & $-0,166854$ & Jarang \\
4 & $-0,166855$ & $-0,041944$ & Jarang \\
5 & $-0,041945$ & 0,082967 & Jarang \\
6 & 0,082968 & 0,207877 & Jarang \\
7 & 0,207878 & 0,332788 & Jarang \\
8 & 0,332789 & 0,457698 & Sedang \\
9 & 0,457699 & 0,582609 & Tinggi \\
\hline \hline (Sumber: Disesuaiakan dengan kisaran tingkat kerapatan \\
Departemen, Kehutanan ) & & \\
\hline
\end{tabular}

Tabel 7. Tingkat Kerapatan Vegetasi Daerah Semak Belukar

\begin{tabular}{cccc}
\hline \hline Kelas & Minimum & Maximum & Kerapatan \\
\hline 1 & 0,345948 & 0,375108 & Sedang \\
3 & 0,375109 & 0,404269 & Sedang \\
4 & 0,404270 & 0,433429 & Sedang \\
5 & 0,433430 & 0,462590 & Tinggi \\
6 & 0,462591 & 0,491750 & Tinggi \\
7 & 0,491751 & 0,520911 & Tinggi \\
8 & 0,520912 & 0,550071 & Tinggi \\
9 & 0,579233 & 0,608392 & Tinggi \\
\hline \hline
\end{tabular}

(Sumber : Disesuaiakan dengan kisaran tingkat kerapatan Departemen, Kehutanan )

\section{Suhu Udara dan Kelembaban Udara}

Stasiun Klimatologi BMKG yang paling dekat dengan area studi adalah Stasiun BMKG Banyuwangi, dimana elevasi stasiun BMKG Banyuwangi \pm 35 meter (mdpl), sedangkan ketinggian area studi memiliki elevasi \pm 1600 meter (mdpl). Temperatur udara akan mengalami penurunan sebesar 0,6 으 setiap kenaikan ketinggian (elevasi) 100 meter, sehingga temperatur udara yang terukur di stasiun banyuwangi mengalami penurunan sebesar $9,6 \circ \mathrm{C}$ jika dikorelasikan dengan temperatur udara di Kecamatan Sempol (elevasi $\pm 1600 \mathrm{~m})$. Suhu udara rata-rata bulanan dari tahun 2008 hingga 2012 ditunjukkan pada grafik di gambar 8. Data kelembaban udara rata-rata bulanan di area studi dari tahun 2008-2012 berdasarkan sumber Stasiun BMKG Juanda (stasiun ID 96633) dapat dilihat di gambar 9. 


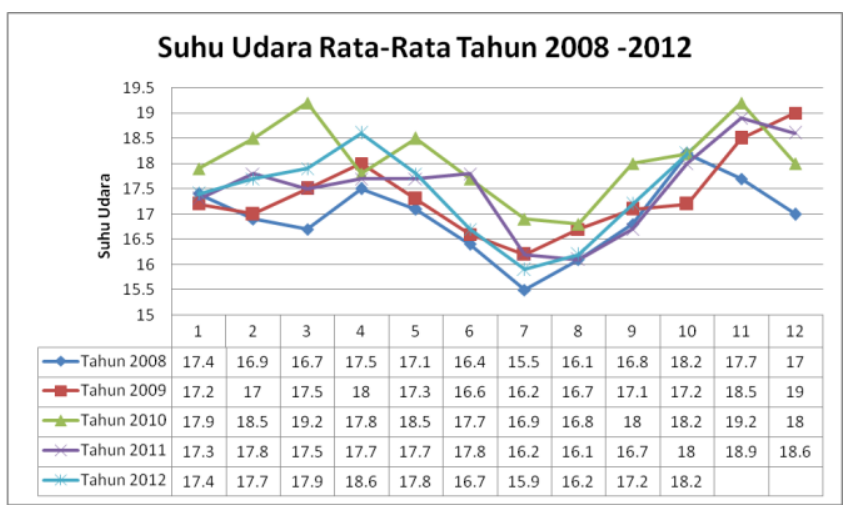

Gambar 8. Suhu Rata-Rata Bulanan Tahun 2008 2012

(Sumber : Disesuaikan dengan stasiun BMKG Banyuwangi)

Berdasarkan grafik di gambar 8, didapatkan suhu rata-rata tertinggi terjadi di bulan Maret dan Nopember di tahun 2010 sebesar 19,2 ${ }^{\circ} \mathrm{C}$ sedangkan nilai terendah terjadi di bulan Juli tahun 2008 sebesar $15,5{ }^{\circ} \mathrm{C}$. Secara umum, nilai suhu rata-rata dari tahun 2008 ke 2010 mengalami peningkatan, dan terjadi penurunan dari tahun 2010 ke 2011. Sedangkan antara tahun 2011 ke 2012 ada yang mengalami peningkatan dan penurunan dengan perubahan yang tidak terlalu tajam.

Kelembaban udara rata-rata di area studi berdasarkan gambar 9 , nilai tertinggi terjadi di bulan Juli tahun 2010 sebesar 84,6 sedangkan nilai terendah terjadi di bulan Juli tahun 2012 sebesar 25,5. Secara umum, terjadi perubahan signifikan dari tahun 2010 ke 2011. Kisaran kedekatan nilai kelembaban rata-rata yang digambarkan di grafik terbagi menjadi dua, yaitu di tahun 2008-2010 dan di tahun 2011-2012.

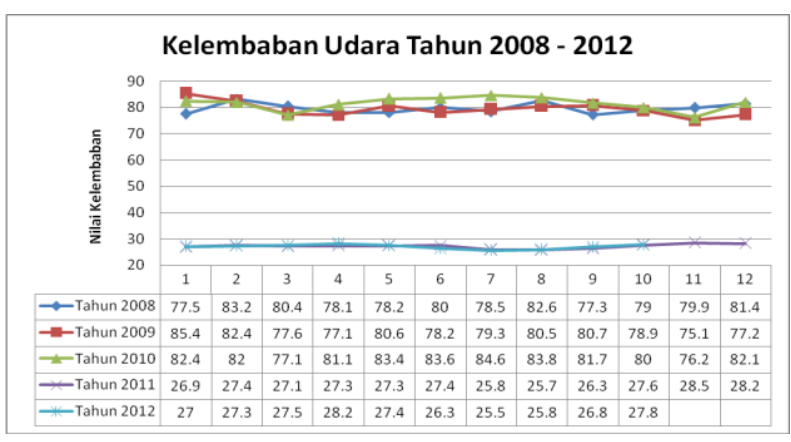

Gambar 9. Kelembaban Udara Rata-Rata Bulanan Tahun 2008-2012

(Sumber : Stasiun BMKG Juanda (stasiun ID 96633)

\section{E. Curah Hujan dan Tipe Iklim}

Berdasarkan data curah hujan ( $\mathrm{mm}$ ), dapat dilihat selama kurun 5 tahun terakhir curah hujan yang terbesar terjadi pada bulan Januari 2012 yaitu $340,1 \mathrm{~mm}$, sedangkan yang minimum terjadi pada bulan September 2011, yaitu hanya $4 \mathrm{~mm}$. Selama kurun waktu 5tahun, bulan kering $(<60 \mathrm{~mm})$ sebanyak 23 bulan, sedangkan bulan basah ( $>100$ $\mathrm{mm}$ ) sebanyak 27 bulan. Berdasarkan jumlah bulan kering dan bulan basah, tipe iklim di daerah studi termasuk iklim sedang.

\section{F. Kondisi Fisik Badan Air dan Tanah}

Secara fisik, kondisi badan air di area studi termasuk dalam Wilayah Aliran Sungai Pekalen dan merupakan Sub DAS Banyuputih. DAS Banyuputih bersumber dari arah utara Kecamatan Sempol lalu bercabang menjadi 3 aliran sungai. Tiga aliran sungai tersebut yakni, Kali Pait, Curah Sibujuk, dan Kali Guci.Beberapa sungai di area studi, termasuk di dalam jenis sungai musiman. Aspek hidrogeologi di area studi memiliki karakteristik lapisan tanah dengan permeabilitas sedang sampai tinggi dan termasuk akifer daerah air tanah langka. Terdapat 3 jenis tanah yang mendominasi area penelitian, yaitu andosol, latosol, dan regosol.

\section{G. Kondisi Topografi}

Area studi memiliki rentang nilai ketinggian antara 362,5 sampai 2950 mdpl. Sebagian besar area studi memiliki ketinggian di atas $1500 \mathrm{mdpl}$ yakni meliputi Desa Jampit, Desa Kalianyar dan Desa Sumberrejo. Klasifikasi kelerengan dibagi menjadi 6 kelas berdasarkan referensi USSSM (United Stated Soil System Management) yaitu (0 - $2 \%($ datar - hampir datar), $>2-6 \%$ ( sangat landai), $>6$ - 13\%( landai), $>13-25 \%$ ( agak curam), >25 $55 \%$ ( curam), dan $>55 \%$ (sangat curam). Derajat kelerengan di area studi dapat dilihat di gambar 10. 


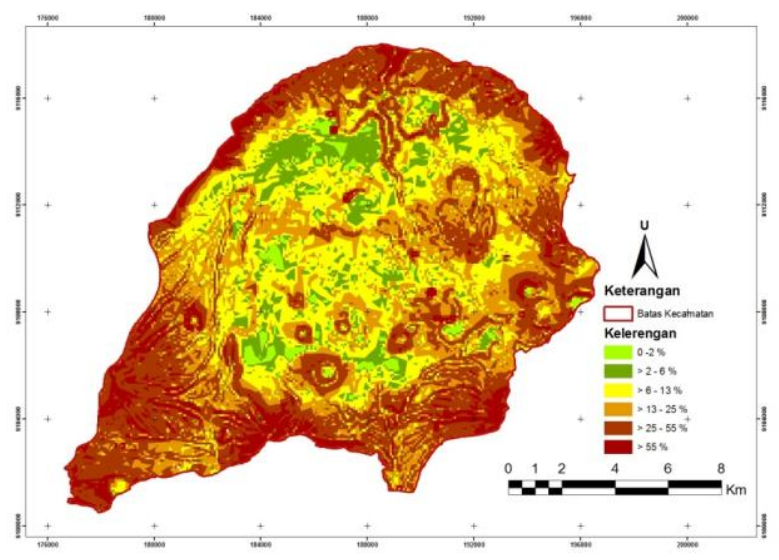

Gambar 10. Derajat Kelerengan di Kecamatan Sempol

\section{KESIMPULAN DAN SARAN}

Berdasarkan hasil penelitian dapat ditarik suatu kesimpulan bahwa:

1. Tutupan lahan di area studi didominasi oleh hutan $(37,58 \%)$, semak belukar $(28,42 \%)$, rumput/tanah kosong $(15,87 \%)$ dan perkebunan(10,27\%).

2. Nilai kerapatan vegetasi di hutan berkisar antara $(-0,542-0,583)$, daerah perkebunan $(0,346-0,608)$ serta daerah semak belukar (0,054-0,532).

3. Suhu udara rata-rata di area studi dari tahun 2008-2012 berada pada rentang nilai $\left(15,5^{\circ} \mathrm{C}\right.$ $\left.19,2^{\circ} \mathrm{C}\right)$. Kelembaban udara rata-rata dari tahun 2008-2012 berkisar antara (25,5 - 84, 6).Selama kurun 5 tahun terakhir (2008 2012), curah hujan yang terbesar terjadi pada bulan Januari 2012 yaitu 340,1 mm. Tipe iklim di area studi termasuk dalam iklim sedang.

4. Area studi memiliki karakteristik lapisan tanah dengan permeabilitas sedang sampai tinggi dan termasuk akifer daerah air tanah langka. Terdapat 3 jenis tanah yang mendominasi yaitu andosol, latosol, dan regosol. Rentang nilai ketinggian di Kecamatan Sempol antara 362,5 sampai $2950 \mathrm{mdpl}$. pengelolaan manajemen dan pelayanan obyek wisata secara profesional

\section{DAFTAR PUSTAKA}

Abidin, HZ, 2002. Penentuan Posisi Dengan GPS Dan Aplikasinya. Pradnya Paramita. Jakarta
Huete, A., Justice, C., Leeuwen, W. V. 1999. MODIS VEGETATION INDEX (MOD 13) ALGORITHM THEORETICAL BASIS DOCUMENT. pdf

Liang, S.2004. Quantitative Remote Sensing of Land Surface. John Willey \& Sons Inc. New Jersey

Lillesand, T.M., Kiefer, R.W., and Chipman J.W.2004. Remote Sensing and Image Interpretation. Fifth Edition. New york : John Wiley \& Sons

Undang-undang Nomor 27 Tahun 2003 tentang Panas Bumi

Undang-undang Nomor 23 Tahun 1997 tentang Pengelolaan Lingkungan Hidup 